Vol 11, Issue 12, 2018

\title{
EVALUATION OF ANTI-ULCER ACTIVITY OF THE ETHANOLIC EXTRACT OF PHYLLANTHUS URINARIA IN EXPERIMENTAL ANIMALS
}

\author{
MANGIRISH N DESHPANDE ${ }^{1,2 *}$, NEELAM BALEKAR $^{3}$ \\ ${ }^{1}$ Department of Pharmacology, P.E.S's Rajaram and Tarabai Bandekar College of Pharmacy, Ponda, Goa, India. ${ }^{2}$ Department of Post \\ Doctoral Studies, School of Pharmacy, RK University, Rajkot, Gujarat, India. ${ }^{3}$ Department of Pharmacology, College of Pharmacy, \\ IPS Academy, Indore, Madhya Pradesh, India. Email: mangirishd@gmail.com
}

Received: 02 July 2018, Revised and Accepted: 27 July 2018

ABSTRACT

Objective: The objective of this study is to investigate the antiulcer activity of the ethanolic extract of Phyllanthus urinaria (EEPU).

Methods: In vivo anti-ulcer activity of EEPU was evaluated in the present study at $500 \mathrm{mg} / \mathrm{kg}$ body weight by pyloric ligation, ethanol-induced ulcer, aspirin-induced ulcer, and cold restraint-induced ulcer model. The anti-ulcer activity was assessed by determining and comparing the gastric volume, $\mathrm{pH}$, free and total acidity, ulcer number and its inhibition, and ulcer severity.

Result: EEPU at $500 \mathrm{mg} / \mathrm{kg}$ body weight dose showed significant antiulcer activity by decreasing ulcer index, gastric volume, pH, and free and total acidity. Gastroprotective effect of EEPU was substantiated by histopathological studies of the stomach in ulcer and treated groups.

Conclusion: It can be concluded from the results that EEPU has potential antiulcer activity.

Keywords: Phyllanthus urinaria, Pylorus ligation, Aspirin, Cold restrain, Antiulcer, Antisecretory, Gastroprotective.

(C) 2018 The Authors. Published by Innovare Academic Sciences Pvt Ltd. This is an open access article under the CC BY license (http://creativecommons. org/licenses/by/4. 0/) DOI: http://dx.doi.org/10.22159/ajpcr.2018.v11i12.28235

\section{INTRODUCTION}

The major population of the world is prone to peptic ulcers, which has become a most prevalent gastrointestinal disorder due to sedentary lifestyle, habituation to junk food, increasing stress, and indiscriminate use of NSAIDS [1]. Peptic ulcer disease occurs due to the alteration of balance between damaging (aggressive) factors such as high acid-pepsin secretion and protective factors (defensive) such as gastromucosal integrity, bicarbonate, and prostaglandin secretion [2]. Helicobacter pylori infection is another major cause of peptic ulcer disease [3].

Many synthetic antiulcer and gastroprotective drugs such as protonpump inhibitors and $\mathrm{H}_{2}$ receptor antagonists are available in the market, but long-term chronic use of which has led to several serious adverse effects such as osteoporosis [4], cardiac arrhythmias, gynecomastia, and impotence [5]. In addition to the side effects, main problem with the synthetic drug therapy is a recurrence of ulcer after 1 year of the end of treatment [6]. Herbal medicines, due to cheaper accessibility, fewer or no side effects, and perceived effectiveness, are unfolding as substitute treatments to available synthetic drugs [7].

Phyllanthus urinaria belonging to genus Phyllanthus (family - Euphorbiaceae) [8] has traditionally being used for jaundice, hepatitis, diarrhea, enteritis, nephritis, edema, and ulcers [9]. Pharmacological studies previously reported are anticancer activity [10], antiviral activity [11], and hypoglycemic activity [12].

The purpose of this investigation was to scientifically reinforce the traditional claim of antiulcer activity of $P$. urinaria plant using different antiulcer models such as ethanol-induced, aspirin-induced, cold restraint stress, and pylorus ligated ulcer model in rats.

\section{METHODS}

Plant material

Fresh plants of P. urinaria were collected from the Western Ghats of Sahyadri region (Anmod-Mollem). The plant was identified and authenticated by Dr. Sangram Keshari Das, MD (Ayu.) PhD., Professor and Head, Department of Drayaguna Vijna, Gomantak Ayurveda Mahavidyalaya and Research Centre, Shiroda, Ponda, Goa.

Plants were carefully washed with water and were dried in the shade. After drying, the whole plant was powdered using an electrical mixer to obtain fine powder and kept in an airtight container.

\section{Chemicals}

Petroleum ether, ethanol, mercuric chloride, potassium iodide, iodine, hydrochloric acid, sodium hydroxide, ferric chloride, acetic anhydride, sulfuric acid, chloroform, glacial acetic acid, Fehling's solution, Benedict's reagent, methanol, and omeprazole were used for this study. All the chemicals used were of high quality and analytical grade.

\section{Preparation of extract}

250 g powder of $P$. urinaria plant was packed in a Soxhlet apparatus and was extracted using $95 \%$ ethanol (2L) at the temperature of $70^{\circ} \mathrm{C}$ after pre-treatment with petroleum ether.

Extract was concentrated, and the solvent was recovered using a rotary evaporator. The concentrated extract was further air dried until blackish semisolid mass was obtained (Fig. 1).

\section{Phytochemical screening}

The ethanolic extract of $P$. urinaria (EEPU) was subjected to preliminary phytochemical screening for the qualitative detection of phytoconstituents such as carbohydrates, proteins, amino acids, steroids, glycosides, flavonoids, and alkaloids [13].

\section{Animals}

Male Wistar albino rats weighing 150-200g were procured from Adita Biosys Pvt. Ltd., Tumkur (1868/PO/Bt/S/16/CPCSEA), and housed in an animal house of PES's Rajaram and Tarabai Bandekar College of Pharmacy, Farmagudi, Goa (RTBCOP), and were acclimatized to the standard condition having room temperature $24 \pm 2^{\circ} \mathrm{C}$ with relative 


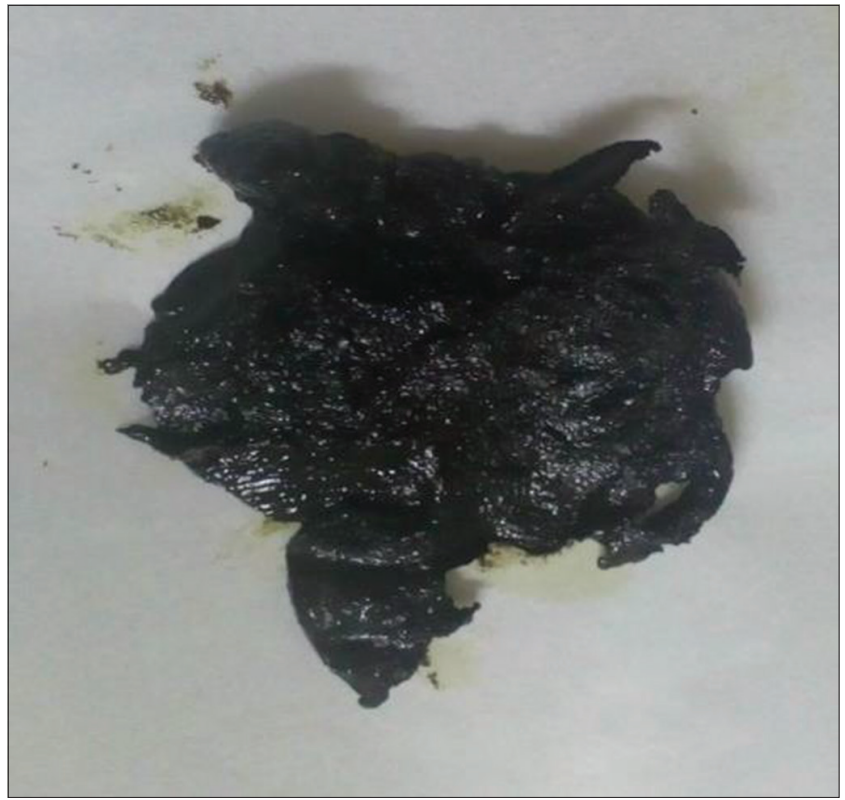

Fig. 1: Ethanolic extract of Phyllanthus urinaria

humidity of $50-60 \%$ and $12 \mathrm{~h}$ light and $12 \mathrm{~h}$ dark cycle. Animals were maintained on synthetic pellet feed and clean water ad libitum. The Institutional Animal Ethics Committee (IAEC) of RTBCOP under the guidance of committee for the purpose of control and supervision of experiments on animals (CPCSEA) approved animal activity of this study with resolution number PESRTBCOP/IAEC;clear/2015-16/R-15.

\section{Acute toxicity studies}

The acute toxicity studies of EEPU were carried on Swiss albino mice (25-30g) with "up and down" acute toxicity as per the method described by the OECD guideline 425 [14]. Group of 5 mice was divided into two groups (male and female) and was deprived of feed for $12 \mathrm{~h}$ with excess to water ad libitum. Treated group received EEPU at the increasing dose of $100 \mathrm{mg}, 500 \mathrm{mg}, 1000 \mathrm{mg}, 2000 \mathrm{mg}$, and $4000 \mathrm{mg} / \mathrm{kg}$ orally and control group received vehicle distilled water $10 \mathrm{ml} / \mathrm{kg}$. Mortality and behavioral changes were observed periodically up to $72 \mathrm{~h}$.

\section{Antiulcer activity of EEPU}

Pylorus ligation-induced ulcer [15]

In pylorus ligation-induced ulcer model, Wistar albino rats were divided into three groups containing six animals each. Group I received normal saline at the dose of $2 \mathrm{ml} / \mathrm{kg}$. Group II received standard drug omeprazole at $20 \mathrm{mg} / \mathrm{kg}$. Group III received EEPU at the dose of $500 \mathrm{mg} / \mathrm{kg}$. For all three groups, drugs were administered orally $1 \mathrm{~h}$ before pylorus ligation. Pylorus ligation was done under ether anesthesia at $35 \mathrm{mg} / \mathrm{kg}$ body weight without causing damage to stomach blood supply. Ligated rats were allowed to recover and were maintained in individual cages. In the post-operative period, animals were deprived of water. $4 \mathrm{~h}$ after pyloric ligation, animals were sacrificed by overdose of ether and the stomach was cut open along the greater curvature to do ulcer scoring. Gastric content was collected to determine gastric juice volume, gastric $\mathrm{pH}$, free acidity, and total acidity [16].

\section{Ethanol induced ulcer}

In ethanol-induced ulcer model, Wistar albino rats were divided into three groups containing six animals each. Group I received normal saline $2 \mathrm{ml} / \mathrm{kg}$ orally. Group II received standard drug omeprazole $2 \mathrm{mg} / \mathrm{kg}$ by oral route, and Group III received EEPU orally at the dose of $500 \mathrm{mg} / \mathrm{kg}$. After 45 min of the drug treatment (omeprazole and EEPU in Groups II and III, respectively), gastric ulcer was induced in rats by administering absolute ethanol at $1 \mathrm{ml} / 200 \mathrm{~g}$. Animals of all three groups were sacrificed post $1 \mathrm{~h}$ of ethanol administration [17]. The stomach was opened along the greater curvature, and ulcer scoring was done [18].

\section{Aspirin-induced ulcer}

In aspirin-induced ulcer model, Wistar albino rats were divided into three groups of six animals. Animals were fasted $36 \mathrm{~h}$ before administration of aspirin. Group I received normal saline at $2 \mathrm{ml} / \mathrm{kg}$, Group II received ranitidine $20 \mathrm{mg} / \mathrm{kg}$, and Group III received EEPU $500 \mathrm{mg} / \mathrm{kg}$ orally. All treatments were administered $1 \mathrm{~h}$ before administration of aspirin. Ulcers were induced by the administration of aspirin orally at the dose of $200 \mathrm{mg} / \mathrm{kg}$. Animals were sacrificed by cervical dislocation after $6 \mathrm{~h}$ of administration of aspirin, and ulcer scoring was done counting the gastric lesion after opening the stomach along the greater curvature [19].

\section{Cold stress restraint ulcer}

Three groups of Wistar albino rats (150-200 g), with each group containing six animals, were used. The first group served as a control (normal saline at $2 \mathrm{ml} / \mathrm{kg}$ orally), second group served as standard (omeprazole at $20 \mathrm{mg} / \mathrm{kg}$ ), and third group served as the test group (EEPU at $500 \mathrm{mg} / \mathrm{kg}$ ). All treatments were administered $1 \mathrm{~h}$ before stress in restraint cages that were kept at $3^{\circ} \mathrm{C} \pm 1^{\circ} \mathrm{C}$ in a refrigerator for $4 \mathrm{~h}$ treatment. After $4 \mathrm{~h}$, the animals were sacrificed by cervical dislocation and gastric lesions were enumerated after opening the stomach along the greater curvature, and ulcer scoring was done [20].

\section{Statistical analysis}

All values are expressed as a mean \pm standard error of the mean, $n=6$, the minimum value of ${ }^{*} \mathrm{p}<0.05,{ }^{* *} \mathrm{p}<0.01,{ }^{* * *} \mathrm{p}<0.001$ as compared to control group (one-way analysis of variance followed by multiple comparison Dunnett's test) [21].

\section{Ulcer score [22]}

Scoring of ulcers was made as follows:

- Normal-colored stomach - 0

- Red coloration - 0.5

- Spot-1

- Hemorrhagic streak - 1.5

- Ulcers - 2

- Perforations - 3

Mean ulcer score for each animal is indicated as ulcer index.

\section{Histopathology studies}

Sections of tissue from the stomach were examined histopathologically to study the effect of EEPU. Slides were prepared at Ashwini Patholabs, Panjim, Goa.

The examination of slides was done microscopically for any pharmacological changes such as hemorrhage, congestion, edema, and erosions using an arbitrary scale for the assessment of the severity of these changes [23].

\section{RESULTS AND DISCUSSION}

\section{Phytochemical screening}

Preliminary phytochemical screening of EEPU showed the presence of flavonoids, glycosides, tannins, and triterpenoids.

\section{Acute toxicity studies}

EEPU did not demonstrate any sign and symptoms of evident toxicity, with no behavioral alteration or changes, and it did not cause animal deaths within $72 \mathrm{~h}$. EEPU was safe until the maximum dose of $4000 \mathrm{mg} / \mathrm{kg}$ of body weight.

\section{Pylorus ligation-induced ulcer}

In this ulcer-induced model, EEPU at the dose of $500 \mathrm{mg} / \mathrm{kg}$ body weight showed significant ulcer reduction as in comparison to control and standard omeprazole. EEPU showed remarkable lowering in ulcer index, gastric volume, gastric $\mathrm{pH}$, total acidity, and free acidity. In the control group, mean ulcer index was $2.033 \pm 0$. 0296, the mean ulcer index of standard group was $0.7933 \pm 0.007$, whereas the ulcer 
Table 1: Effect of EEPU on various parameters in pylorus ligated-induced ulcer

\begin{tabular}{|c|c|c|c|c|c|c|}
\hline Treatment groups & Dose & Mean ulcer index & Gastric volume & Gastric pH & $\begin{array}{l}\text { Free acidity } \\
\text { (mEq/l/100 g) }\end{array}$ & $\begin{array}{l}\text { Total acidity } \\
(\mathrm{mEq} / \mathrm{l} / 100 \mathrm{~g})\end{array}$ \\
\hline Control (normal saline) & $2 \mathrm{ml} / \mathrm{kg}$ & $2.033 \pm 0.0296$ & $3.050 \pm 0.1335$ & $3.633 \pm 0.1892$ & $35.54 \pm 0.99$ & $55.62 \pm 1.04$ \\
\hline Standard (omeprazole) & $20 \mathrm{mg} / \mathrm{kg}$ & $0.7933 \pm 0.0071^{* * *}$ & $1.7170 \pm 0.1922^{* * *}$ & $5.733 \pm 0.0918^{* * *}$ & $14.06 \pm 0.61^{* *}$ & $24.14 \pm 0.81^{* *}$ \\
\hline EEPU & $500 \mathrm{mg} / \mathrm{kg}$ & $0.92 \pm 0.045^{* *}$ & $2.383 \pm 0.1887^{*}$ & $4.5500 \pm 0.02473^{* *}$ & $22.25 \pm 0.52^{* *}$ & $34.68 \pm 0.79 * *$ \\
\hline
\end{tabular}

${ }^{*} \mathrm{p}<0.05,{ }^{* *} \mathrm{p}<0.01,{ }^{* * *} \mathrm{p}<0.001$ standard group as compared to control group. EEPU: Ethanolic extract of Phyllanthus urinaria

Table 2: Effect of EEPU on various parameter in cold restrain, ethanol-induced, and aspirin-induced ulcer model

\begin{tabular}{llll}
\hline Treatment groups & Cold stress restraint ulcer & Ethanol-induced ulcer & Aspirin-induced ulcer \\
\hline Control & $5.267 \pm 0.3333$ & $2.360 \pm 0.06439$ & $2.3750 \pm 0.0853$ \\
Standard omeprazole $20 \mathrm{mg} / \mathrm{kg}$ & $2.500 \pm 0.1807^{* * *}$ & $0.5700 \pm 0.0459^{* * *}$ & $0.5750 \pm 0.03354^{* * *}$ \\
EEPU $500 \mathrm{mg} / \mathrm{kg}$ & $3.867 \pm 0.1563^{* *}$ & $1.517 \pm 0.041^{* * *}$ & $1.350 \pm 0.2078^{* * *}$ \\
\hline
\end{tabular}

EEPU: Ethanolic extract of Phyllanthus urinaria

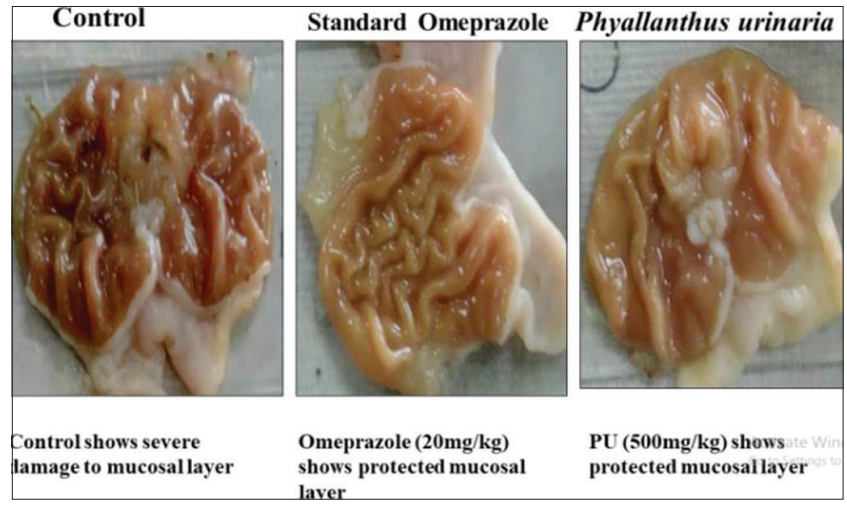

Fig. 2: Ethanolic extract of Phyllanthus urinaria showing significant gastric mucosal layer protection as compared to control and significant with standard

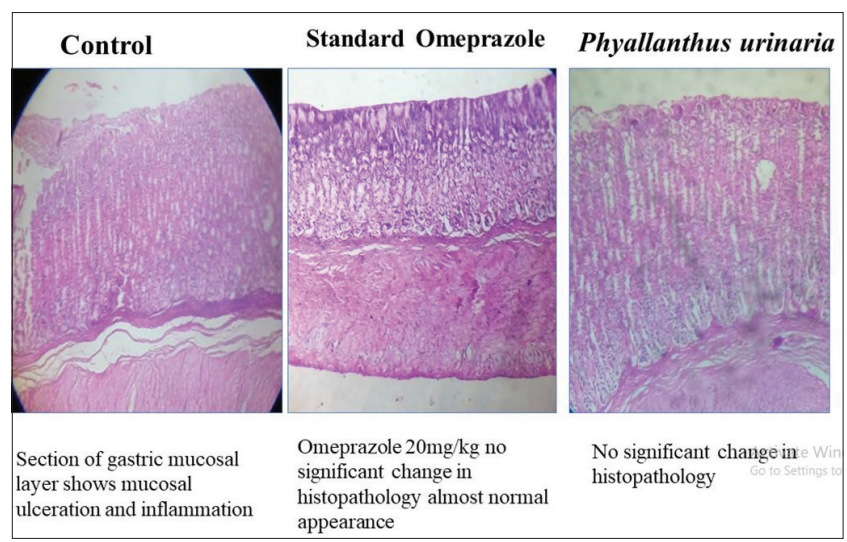

Fig. 3: Histopathology of rat stomach layer in pylorus-ligated ulcer model

index of EEPU was $0.92 \pm 0.045$ (Table 1 ). It is clearly evident from the macroscopic photograph that there is damage to the mucosal layer of the control, whereas EEPU shows significant protection of gastric mucosal layer relevant to standard (Fig. 2). Histopathological slides reinforce the above observations (Fig. 3).

\section{Ethanol-induced ulcer}

In ethanol-induced ulcer model, there was significant damage to the gastric mucosal layer in control group, and EEPU-treated group showed comparatively good prevention of gastric mucosa in which results are compared to standard omeprazole-treated group (Figs. 4 and 5). Mean ulcer index of EEPU-treated group was $1.517 \pm 0.041^{* * *}$ which showed better results as compared to control group which had mean ulcer index $2.360 \pm 0.06439$ (Table 2).

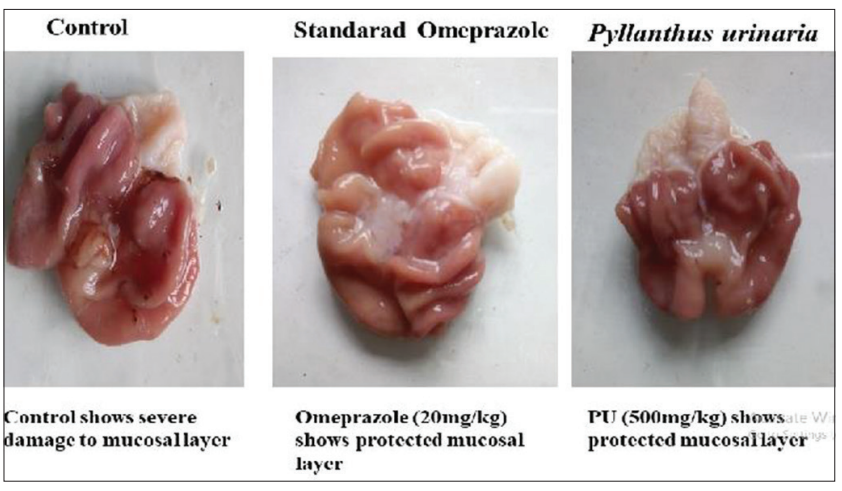

Fig. 4: Rat stomach of ethanol-induced ulcer model

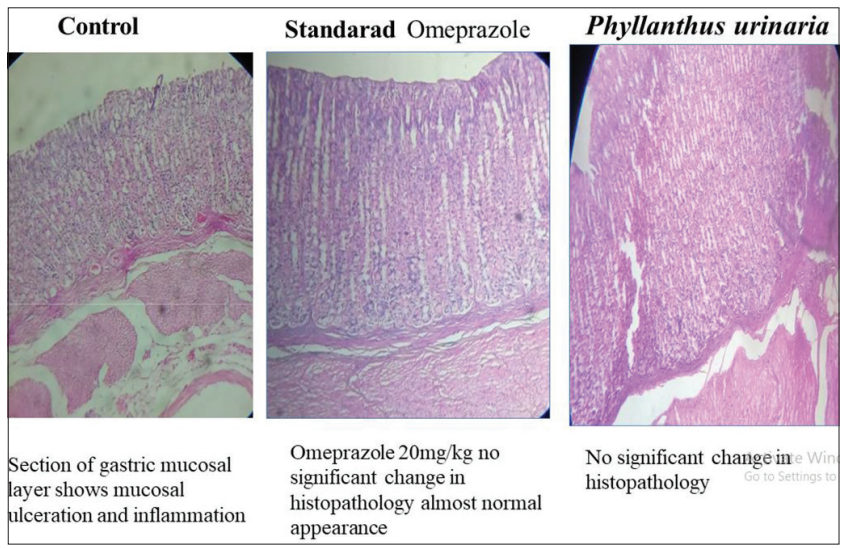

Fig. 5: Histopathology of rat stomach layer in ethanol-induced ulcer model

Aspirin-induced ulcer

In aspirin-induced ulcer model, EEPU showed ulcer protective activity with mean ulcer index $1.350 \pm 0.2078^{* * *}$ which is near to standard group treated with omeprazole which showed protection of gastric layer with mean ulcer index $0.5750 \pm 0.03354^{* * *}$ (Figs. 6 and 7). Control group showed significant damage to the mucosal layer with mean ulcer index $2.3750 \pm 0.0853$ (Table 2).

\section{Cold stress-restraint ulcer}

It is evident that ulcer index of EEPU-treated group was less than the control group in cold stress-restraint ulcer model. From a macroscopic photograph and histological slides, it is clear that EEPU at a dose of $500 \mathrm{mg} / \mathrm{kg}$ showed better gastric mucosal protection (Figs. 8 and 9). Ulcer index of EEPU was $3.867 \pm 0.1563^{* *}$, whereas of standard omeprazole, was $2.500 \pm 0.1807^{* * *}$ which was better than control group $5.267 \pm 0.3333$ (Table 2). 


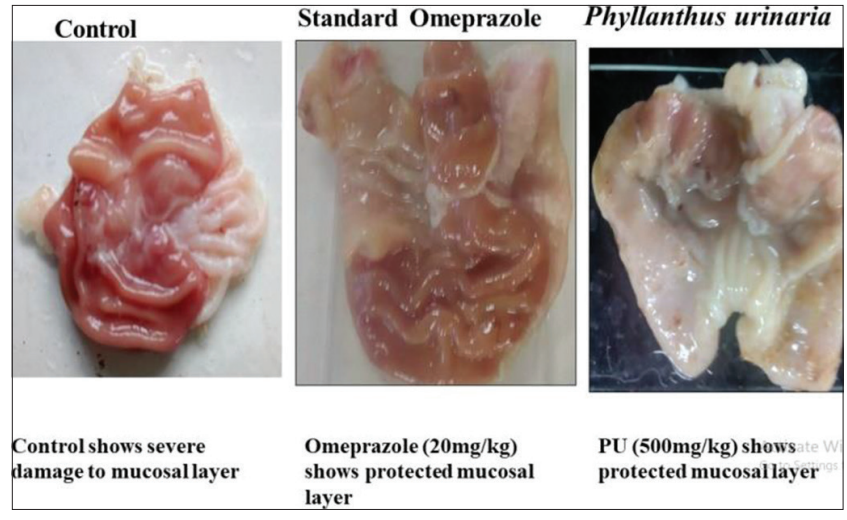

Fig. 6: Rat stomach of aspirin-induced ulcer model

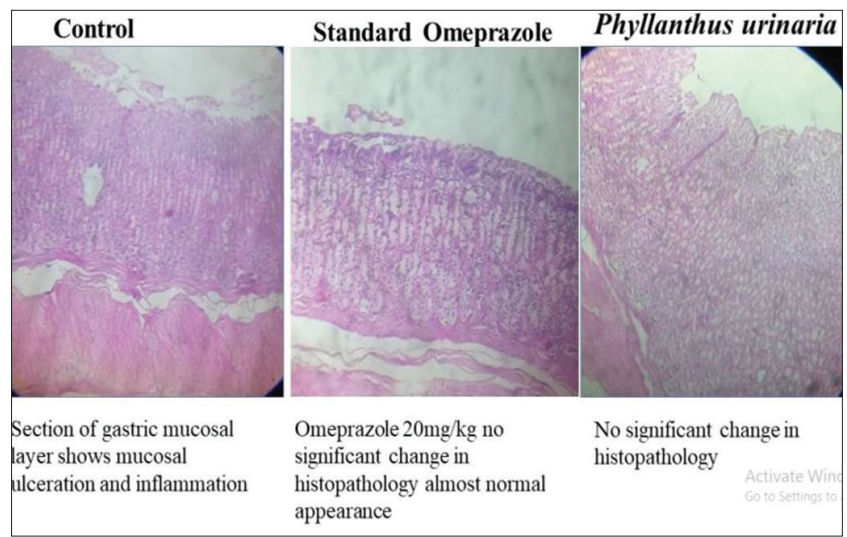

Fig. 7: Histopathology of rat stomach layer in aspirin-induced ulcer model

The plants of genus Phyllanthus have been used traditionally to treat cough and bronchitis and for the treatment of fever and skin disease [24]. P. urinaria is a herbal plant belonging to genus Phyllanthus and family Euphorbiaceae which is being traditionally used in Ayurvedic system of medicines for various ailments including liver disease [25].

Peptic ulcer disease occurs due to the alteration of balance between damaging (aggressive) factors such as high acid-pepsin secretion and protective factors (defensive) such as gastromucosal integrity, bicarbonate, and prostaglandin secretion [26]. H. pylori infection is another major cause of peptic ulcer disease [27].

Literature survey revealed that in vitro studies have shown that P. urinaria inhibits H. pylori [28], so in the present work, in vivo antiulcer activity of EEPU was studied using different ulcer models such as pylorus ligation-induced ulcers, aspirin-induced ulcer, ethanolinduced ulcer, and cold restraint-induced ulcer. Some of the most probable causes of ulcers which occur in humans are represented by these models [29].

EEPU at the oral dose of $500 \mathrm{mg} / \mathrm{kg}$ has shown a potential antiulcer activity in pylorus ligation-induced ulcer model which is representative of ulcers formed due to the buildup of acid in the stomach which by interfering with gastric blood circulation causes gastric ulceration [30,31]. EEPU is effective in reducing total acidity, free acidity, gastric volume, and increase in $\mathrm{pH}$.

In ethanol-induced ulcer model, EEPU at an oral dose of $500 \mathrm{mg} / \mathrm{kg}$ has significantly provided gastric mucosal protection from ulcers which are produced by peripheral damage to the gastric cells which occurs due to injury associated with the significant production of oxygen free radicals causing increase lipid peroxidation $[32,33]$.

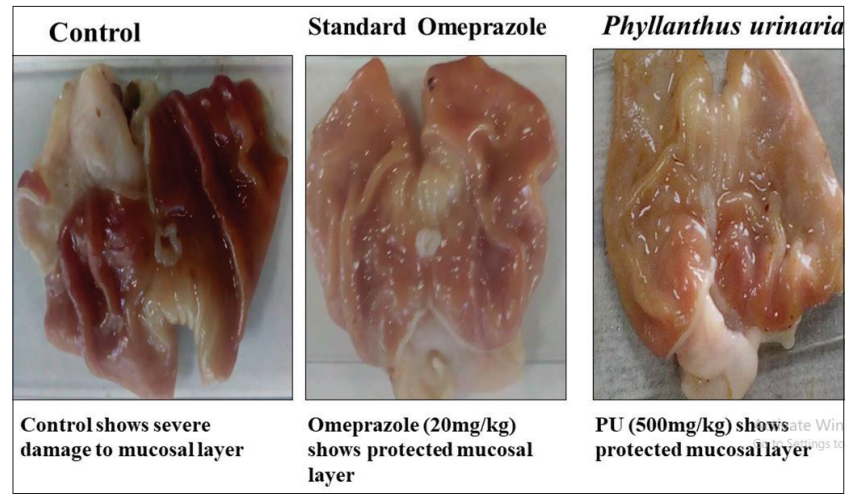

Fig. 8: Rat stomach of cold stress restraint ulcer model

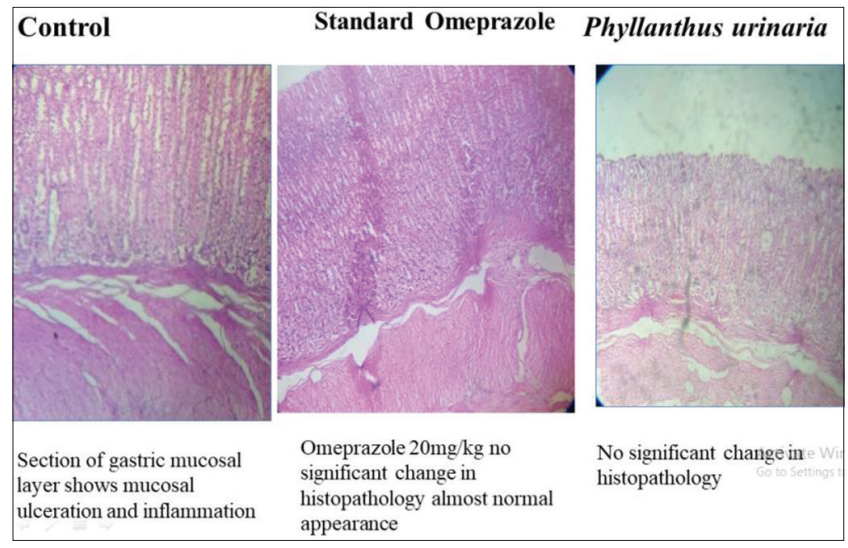

Fig. 9: Histopathology of rat stomach layer in cold stress-restraint ulcer model

EEPU was significantly effective in ulcers caused due to mucosal damage due to a decrease in prostaglandin levels because of the inhibition of prostaglandin synthesis as represented by aspirin-induced ulcer model [34].

In cold-restraint stress model, stress leads to gastric hypermotility and mucosal over friction which are prime causes of ulcer production [35]. EEPU may be effective in stress-related ulcers.

Natural products contain various important biologically active constituents such as tannins, flavonoids, alkaloids, amino acids, and terpenes which have been reported having an antiulcer effect [36]. EEPU have revealed the presence of bioactive compounds such as flavonoids, glycosides, and tannins which might be responsible for the anti-ulcer activity of $P$. urinaria.

\section{CONCLUSION}

It can be concluded on the basis of the results that EEPU possesses antiulcer activity which supports its traditional use.

\section{ACKNOWLEDGMENT}

The authors would like to thank Principal Dr. S. N. Mamle Desai for granting permission to use the institute facilities to carry out my research work. Our sincere thanks to my guide Dr. Neelam Balekar for her guidance and support throughout the work. The authors also thank Dr. D. K. Jain Director, IIP, Indore, for his constant motivation.

\section{AUTHORS' CONTRIBUTION}

Mangirish Deshpande author for this publication, research scholar RK University, and working as Assistant Professor has carried out all the above research work in Pharmacology Laboratory of PES's Rajaram and 
Tarabai Bandekar College of Pharmacy under the guidance of Dr. Neelam Balekar, Principal College of Pharmacy, IPS Academy, Indore, MP.

\section{CONFLICTS OF INTEREST}

The authors have none to declare.

\section{REFERENCES}

1. Peskar BM, Maricic N. Role of prostaglandins in gastroprotection. Dig Dis Sci 1998;43:23-9.

2. Govindarajan R, Vijaykumar M, Singh M, Rao CV, Shirwaikar A, Rawat AK, et al. Antiulcer and antimicrobial activity of Anogeissus latifolia. J Ethnopharmacol 2006;106:57-61.

3. Beltrán-Anaya FO, Poblete TM, Román-Román A, Reyes S, de Sampedro J, Peralta-Zaragoza O, et al. The EPIYA-ABCC motif pattern in cagA of Helicobacter pylori is associated with peptic ulcer and gastric cancer in Mexican population. BMC Gastroenterol 2014;14:223.

4. Panday K, Gona A, Humphrey MB. Medication-induced osteoporosis: Screening and treatment strategies. Ther Adv Musculoskelet Dis 2014;6:185-202.

5. Akthar MS, Akthar AH, Khan MA. Antiulcerogenic effects of Ocimum basilicum extracts, volatile oils and flavanoids glycosides in albino rats. Int J Pharm 1992;30:97-104.

6. Kangwan N, Park JM, Kim EH, Hahm KB. Quality of healing of gastric ulcers: Natural products beyond acid suppression. World J Gastrointest Pathophysiol 2014;5:40-7.

7. Karim A, Nouman M, Munir S, Sattar S. Pharmacology and phytochemistry of Pakistani herbs and herbal drugs used for treatment of diabetes. Int J Pharmacol 2011;7:419-39.

8. Schmelzer GH, Gauribfakim A, Arroo R, Bosch CH, De Ruijter A, Simmonds MS. Plant Resources of Tropical. Africa Wageningen (Netherland): Backhuys Publisher; 2008.

9. Sheng TH, Jong HP, Rong CY. Anticancer effects of Phyllanthus urinaria and relevant mechanisms. Chang Gung Med J 2002;33:477-87.

10. Zhong Y, Zuo C, Li F. Chemical constituents of Phyallanthus urinaria L. And its antiviral activity against hepatitis B virus. Zhongguo Zhong Yao Za Zhi 1998;23:363-84.

11. Gurg M, Garg C. Effect of Phyllanthus urinaria in biochemical profile of experimental hyperglycemic albino rats. Res J Pharm Sci 2012;1:2-6.

12. Singh A. Compendia of World's Medicinal. Florida: CRC Press; 2006. p. 206.

13. Trease GE, Evans WC. Pharmacognosy. 11 $1^{\text {th }}$ ed. London: Bailliere Tindalland Company Publisher; 2005. p. 137-9.

14. OECD. Test No. 425: Acute Oral Toxicity: Up-and-Down Procedure, OECD Guidelines for the Testing of Chemicals, Section 4. Paris: OECD Publishing; 2008

15. Ishii Y. Critical studies of the pylorus ligated rat (Shay rat). Jpn J Pharmacol 1969;19:125-33.

16. Madden RJ, Ramsburg HH, Hundley JM. A critical study of the shay rat. Gastroenterology 1951;18:119-27.

17. Malairajan P, Gopalakrishnan G, Narasimhan S, Veni KJ, Kavimani S. Anti-ulcer activity of crude alcoholic extract of Toona ciliata Roemer (heart wood). J Ethnopharmacol 2007;110:348-51.

18. Surana SJ, Tatiya AU, Jain AS, Ushir YV. Antiulcer activity of Eranthemum roseum (Vahl) R. Br on ethanol induced ulcer in albino rats. Int J Pharmacol Biol Sci 2007;1:65-9.

19. Bodhankar SL, Jain BB, Ahire BP, Dande RB, Shitole PP. The effect of rabeprazole and its isomer on aspirin and histamine induced ulcer in rats. Indian J Pharmacol 2006; 38:357-8.

20. Huilgol SV, Jamadar MG. Gastroprotective role of bioflavonoid silymarin in animal model of acute cold-restraint stress induced gastric ulceration. Al Ameen J Med Sci 2013;6:40-3.

21. Kim HY. Statistical notes for clinical researchers: Post-hoc multiple comparisons. Restor Dent Endod 2015;40:172-6.

22. Kulkarni SK. Practical Pharmacology and Clinical Pharmacy. $1^{\text {st }}$ ed. New Delhi: Vallabh Publication; 2007. p. 186.

23. Culling CF. Handbook of Histopathological and Histochemical Techniques. London: Butterwirth and Co.; 1974. p. 37.

24. Anusha JR, Remya RV, Sasi Premila JM, Albin TF. Antioxidant and anticandidal activity studies on phyllanthin compound from Phyllanthus niruri. Int J Pharm Pharm Sci 2014;6:323-6.

25. Calixto JB, Santos AR, Filho VC, Yunes RA. A review of the plants of the genus Phyllanthus: Their chemistry, pharmacology and therapeutic potential. Med Res Rev 1998;18 Suppl 4:225-58

26. Balekar NS, Jain DK, Jawanjal H. Evaluation of antiulcer activity of bark extract of Albizzia lebbeck Linn. South Pac J Pharma Bio Sci 2013;1:43-50.

27. Lubenz J, Borsch G. Role of Helicobacter pylori eradication in the prevention of peptic ulcer bleeding relapse. Digestion 1994;55 Suppl 1:19-23.

28. Lai CH, Fang SH, Rao YK, Geethangili M, Tang CH, Julin Y, et al. Inhibition of Helicobacter pylori-induced inflammation in human gastric epithelial AGS cells by Phyllanthus urinaria extracts. J Ethnopharmacol 2008;118 Suppl 3:522-26.

29. Patil P, Prakash T, Shivakumar H, Pal S. Anti-ulcer and anti-secretory properties of the Buteamono sperma (Lam) bark extract with relation to antioxidant studies. Iran J Pharmacol Ther 2009;8:1-6.

30. Brodie DA. The mechanism of gastric hyperacidity produced by pylorus ligation in the rat. Am J Dig Dis 1966;11:231-41.

31. Devi MR, Subramanian NS, Anbazhagan S, Telrandhe UB. Anti-gastric ulcer activity of Ficus nervosa bark in wistar albino rats. J Chem Pharm Res 2012;4:1288-95.

32. Muthu S, Nagarajan A, Palanisamy B. Antiulcerogenic effect of resin from Shorea robusta Gaertn. F. on experimentally induced ulcer models. Int J Pharm Pharm Sci 2013;5 Suppl 1:269-72.

33. Balekar NS, Jain DK, Dixit PV, Badoriya SS. Evaluation of antiulcer activity of whole plant extract of Malvastrum tricuspidatum in experimental animals. Iran J Pharmacol Ther 2012;11 Suppl 2:53-9.

34. Allison MC, Howastson AG, Torrance CJ, Lee FD, Russel RI. Gastrointestional damage associates with the use of non-steroidal antiinflammatory drugs. N Engl J Med 1992;327:749-54.

35. Qui BS, Mei QB, Liu L, Wong KM. Effects of nitric oxide on gastric ulceration induced by nicotine and cold-restraint stress. World $\mathrm{J}$ Gastroenterol 2004;10:594-7.

36. Borrelli F, Izzo AA. The plant kingdom as a source of anti-ulcer remedies. Phytother Res 2000;14:581-91 